\title{
Article \\ Biogas Generation from Maize and Cocksfoot Growing in Degraded Soil Enriched with New Zeolite Substrate
}

\author{
Mariola Chomczyńska *, Małgorzata Pawłowska, Oliwia Szczepaniak ${ }^{\dagger}$ and Ewelina Duma ${ }^{\dagger}$ \\ Environmental Engineering Faculty, Lublin University of Technology, Nadbystrzycka 40B Str., \\ 20-618 Lublin, Poland; m.pawlowska@pollub.pl (M.P.); o.szczepaniak@o2.pl (O.S.); \\ ewelina.dumaa@gmail.com (E.D.) \\ * Correspondence: m.chomczynska@pollub.pl; Tel.: +48-81-538-4404 \\ + Graduated Students.
}

Citation: Chomczyńska, M.; Pawłowska, M.; Szczepaniak, O.; Duma, E. Biogas Generation from Maize and Cocksfoot Growing in Degraded Soil Enriched with New Zeolite Substrate. Energies 2022, 15, 377. https://doi.org/10.3390/ en15010377

Academic Editor: Attilio Converti

Received: 27 November 2021

Accepted: 1 January 2022

Published: 5 January 2022

Publisher's Note: MDPI stays neutral with regard to jurisdictional claims in published maps and institutional affiliations.

Copyright: (C) 2022 by the authors. Licensee MDPI, Basel, Switzerland. This article is an open access article distributed under the terms and conditions of the Creative Commons Attribution (CC BY) license (https:// creativecommons.org/licenses/by/ $4.0 /)$.

\begin{abstract}
Degraded lands are potential areas for obtaining biomass which can serve as an energy source after its conversion into biogas. Thus, the studies on biogas production from maize and cocksfoot biomasses obtained from degraded soil supplemented with additions of new zeolite substrate (Z-ion as the nutrient carrier) and on arable soil (reference soil) were carried out during batch digestion tests. It was found that the biogas and biomethane potentials and specific energy of the test species growing in degraded soil enriched with Z-ion additions $(1 \%$ and $5 \% \mathrm{v} / \mathrm{v}$ in the cases of cocksfoot and maize, respectively) did not differ significantly from the values of these parameters that were found for the plants growing in arable soil. The application of Z-ion to the degraded soil (especially in a dose of $5 \% \mathrm{v} / \mathrm{v}$ ) resulted in an increase in the nitrogen content and decrease (below the lower optimum value) in the $\mathrm{C} / \mathrm{N}$ ratio in the plant biomass. However, these changes did not negatively influence the final values of the biogas or methane potentials or the specific energy found for the maize biomass. Therefore, the study results indicated the usefulness of Z-ion substrate for improving the growth conditions for energy crops in degraded soils and, as a consequence, obtaining a plant feedstock suitable for the digestion process.
\end{abstract}

Keywords: biogas; anaerobic digestion; energy crops; Z-ion substrate; marginal and degraded soils

\section{Introduction}

Due to the depletion of conventional fuels and the need to reduce carbon dioxide emissions as well as minimize waste generation, the progress of civilization and the development of industry require the use of alternative methods of obtaining energy, mainly from renewable sources. One of the most important is biomass, which is distinguished from the other sources by two features. First, it is characterized by a low conversion efficiency of sunlight into the energy stored primarily in plants (1-3\%), which implies that a much higher land area is required to indirectly acquire solar energy via terrestrial biomass cultivation than by more concentrated wind-, hydro-, or direct solar energy systems. Secondly, biomass constitutes the "stuff of life" of the Earth. Thus, any change in biomass production (for instance, by replacing natural vegetation with cultivated plant varieties, enhancing crop yields) could have beneficial or harmful effects on the functioning of ecosystems and thus on human life [1].

One way to use biomass for energy purposes is, among other applications, the anaerobic digestion process, resulting in the generation of biogas (containing $60-70 \%$ methane) and an organic residue (a digestate) rich in nitrogen [2-4]. Anaerobic digestion is a multistage process involving anaerobic and relatively anaerobic microorganisms [5]. These microbiota belong to the trophic groups defined as hydrolytic, fermentative, acetogenic, and methanogenic ones fulfilling specific functions in the transformation of organic matter during the fermentation process [3,6]. In fact, hydrolytic bacteria break down organic macromolecular compounds to monomeric and dimeric solubles (monosugars, amino 
acids, and fatty acids). Fermentative bacteria consume hydrolysis products, and thus they produce short-chain fatty acids (e.g., acetic acid), alcohols, aldehydes, carbon dioxide, and hydrogen. Acetogenic bacteria are responsible for the conversion of fermentative bacteria metabolites to acetic acid and hydrogen. Methanogenic microorganisms produce methane from acetate (acetotrophic methanogens) or from carbon dioxide and hydrogen (hydrogenotrophic methanogens).

Biogas is a carbon-neutral source of renewable energy and can be used to produce heat, power, transport biofuel, as well as chemicals like methanol, acetic acid, or dimethyl ether $[2,7,8]$. The biogas generation realized with the use of well-established technologies in biogas plants is based on a broad array of feedstocks, like an organic fraction of urban waste, animal manure and slurry, agricultural byproducts, or energy crops $[4,9,10]$. Among energy crops, annual (e.g., maize, fodder and sugar beets, and cereals) and perennial species (e.g., grasses like cocksfoot, tall fescue, perennial ryegrass, and timothy) are recommended for biogas production $[2,7,10]$. The choice of crop as the feedstock for biogas plants is dependent on many parameters, including biomass yield, chemical composition, energy, nutrient and pesticide inputs during crop cultivation, harvest and storage costs, and the ease of cultivation, harvesting, and storage [2]. Energy crops may be grown in agricultural areas, but considering the issue of competition for land for food and fodder production [1,9], it has been proposed for some time to grow energy species on marginal lands [11,12]. Marginal lands include inter alia the soils degraded for various reasons (e.g., contaminated, exhausted, or geomechanically distorted areas); thus, energy crop cultivation on such lands is not only beneficial from the point of view of the subsequent use of biomass for energy purposes, but it also gives the possibility of land reclamation, contributing to the renewal of the natural environment [13]. It is known that the presence of plants in degraded soils causes an increase in organic matter (e.g., tissue residues), which is the starting material for the humus forming process and provides nutrients for microbiota, affecting their species richness, biomass, and enzymatic activity [14-16]. Moreover, cultivating perennial energy species, particularly grasses, can mitigate the erosion of a degraded area and favors carbon sequestration with the reduction of greenhouse gas emissions, creating wildlife habitats or increasing biodiversity $[7,17]$. The usefulness of reclaimed land or low-quality land for the production of biomass of energy crops has become a subject of research in recent years, although the results are not unequivocal. Blanco-Canqui [18] stated that such applicability of reclaimed land depends on many factors, including soil quality, plant species, and environmental conditions, which determine the biomass yield and translate into the economic viability. On a global scale, the total degraded area is estimated to be 2000 Mha [19], while the marginal soils are estimated to be 2700 Mha [20]. According to Zhang et al. [21], in China alone, 59 Mha of marginal lands are suitable for cultivating perennial energy crops, such as switchgrass and miscanthus. Li et al. [22] estimated that the energy potential of these crops is ca. $20 \mathrm{EJ}(20 \cdot 1018 \mathrm{~J})$. In addition to the undoubted beneficial effects on the environment resulting from preventing erosion, improving soil properties, or reducing the consumption of fossil fuels, the positive social impact of such use of biomass harvested from low-quality soils is emphasized. Including land unsuitable for food production in the production of energy crops improves food security in the long term [20].

The use of biogas for energy production is an environmentally beneficial method of energy production, although in economic terms, it is a costly process due to high investment costs. Amaral et al. [23] claims that without subsidy policies, the energy production from biogas does not attain economic self-sustainability. However, it should be taken into account that the economic balance of a biogas plant depends on many factors, including the power of the biogas plant, the type of raw material used, its availability, the adopted biogas production technology, the method of its further use, or the method of digestate management. Therefore, biogas plants that use the cheap feedstocks can achieve a short payback period. According to the research of Wagner et al. [24], the costs of production and utilization of the biogas recovered from biomass of miscanthus cultivated on marginal 
land are considerably lower than those of maize. However, the authors emphasize that the economic sustainability of using biomass derived from such a land is limited by the biomass yield.

Growing energy plants in degraded soils requires agrotechnical management practices, such as the application of mineral fertilizers in different forms, among others. Such materials may include ion exchange substrates first developed at the Institute of Physical and Organic Chemistry of the National Academy of Sciences of Belarus in Minsk (IPOCHNASB). These are mixed cation and anion exchangers loaded with plant nutrient ions in proper ratios $[25,26]$. The high exchange capacity of ion exchangers, which are applied to the degraded soils in a relevant doses, ensures a greater nutrient content in the substrates compared with that of the most fertile natural soils. The macro- and micronutrients contained in the ion exchangers are osmotically inactive; hence, it is impossible to damage the plant roots [27]. The previous studies showed that adding ion exchange substrates in small amounts (equal to $2 \% \mathrm{v} / \mathrm{v}$ ) to sand (used as a degraded soil model) increased the biomass yield of plants from 4 to 13 times, depending on the substrate variants and plant species [28]. Currently, financial considerations limit the common use of substrates prepared from synthetic ion exchangers. Therefore, the workers of IPOCH-NASB prepared new substrates comprising only more cost-effective natural ion exchangers (i.e., zeolites) [29]. These substrates are produced under the "Z-ion" trademark as mixtures of potassium and ammonium forms of clinoptilolite with added weakly soluble calcium and magnesium phosphates. The variants of $Z$-ion substrates vary in terms of the nominal molar ratios of $\mathrm{NH}_{4}{ }^{+} / \mathrm{K}^{+}$(ranging from $1 / 1$ to $4 / 1$ ) as well as in regard to the $\mathrm{pH}$ values (equal to 5,6 , or 7). Equivalent ion exchange of potassium and ammonium ions with plant metabolites, as well as the low solubility of the $\mathrm{Ca}$ and $\mathrm{Mg}$ phosphates, control the concentration of nutrients in the solution equilibrated with the substrate type. This ensures constant total ionic concentration in the substrate water solution which is safe for the plants, regardless of the amount of the zeolite substrate in the growing media [29].

Considering the possibility to enhance the development of energy crops in degraded soils with the use of a new zeolite substrate, the preliminary study aimed to (1) determine the biogas and methane potentials of biomass of maize (Zea mays L.) and cocksfoot (Dactylis glomerata L.) growing in degraded soil supplemented with Z-ion additions and (2) compare the biogas and methane potentials obtained for the species mentioned above with those determined for the plants growing in the reference arable soil.

\section{Materials and Methods}

The study was performed in two stages. The first one was cultivation of maize and cocksfoot in degraded soil enriched with Z-ion additions and in arable soil to obtain biomass used as feedstocks for anaerobic digestion. The second one was batch assays of anaerobic digestion of maize and cocksfoot shoot biomass harvested in the first stage, enabling us to obtain the biogas production characteristics.

\subsection{Plant Growing}

Energy crops were grown for 6 weeks in pot systems. Maize was cultivated in spring 2019 and cocksfoot in autumn 2019 under phytotron conditions (13/11 photoperiod, $25 \pm 1 / 16 \pm 1{ }^{\circ} \mathrm{C}$ day/night temperature). For cultivation of both test species, the growing media were prepared with the use of degraded soil, arable soil, and Z-ion substrate. The Z-ion substrate (a nutrient carrier) was manufactured in line with the IPOCH-NASB procedure at the "Project WISMUT" Ltd. plant (Russia). The substrate contained the following nutrient amounts $\left(\mathrm{mmol} \mathrm{kg}^{-1}\right)$ : nitrogen, 324; phosphorus, 100; potassium, 110; calcium, 113; magnesium, 80; sodium, 101; and sulfur, 1.4. The degraded soil was harvested from the edge zone of the excavation of sand mine in Rokitno (Lublin province, Poland). The soil was acidic and contained low sulfur and very low phosphorus, potassium, and magnesium, as well as insufficient nitrogen and calcium amounts regarding the plant requirements (Table 1). The arable soil was taken from a farm located in Czesławice (Lublin 
province, Poland). The soil was slightly acidic and was characterized by low sulfur, high potassium, very high or high magnesium, and very high phosphorus contents (Table 1). The nitrogen and calcium amounts were greater than in the degraded soil, but they were insufficient in terms of plant needs. Therefore, the arable soil could be considered that of a medium quality.

Table 1. Characteristics of soils used for plant cultivation.

\begin{tabular}{|c|c|c|c|c|c|c|c|c|c|c|c|c|c|c|c|c|}
\hline \multirow{4}{*}{ Soil } & \multirow{2}{*}{\multicolumn{2}{|c|}{$\begin{array}{c}\mathrm{pH} \\
\text { (in } 1 \mathrm{M} \mathrm{KCl} \text { ) }\end{array}$}} & \multicolumn{14}{|c|}{ Plant Available Nutrients } \\
\hline & & & \multicolumn{2}{|c|}{$\begin{array}{c}\mathrm{N}-\mathrm{NH}_{4} \\
\left(\mathrm{mg} \mathrm{kg}^{-1}\right) \\
\left(\mathrm{mg} \mathrm{dm}^{-3}\right)\end{array}$} & \multicolumn{2}{|c|}{$\begin{array}{c}\mathrm{N}-\mathrm{NO}_{3} \\
\left(\mathrm{mg} \mathrm{kg}^{-1}\right) \\
\left(\mathrm{mg} \mathrm{dm}^{-3}\right)\end{array}$} & \multicolumn{2}{|c|}{$\begin{array}{c}\mathrm{P}_{2} \mathrm{O}_{5} \\
(\mathrm{mg} \text { per } 100 \mathrm{~g})\end{array}$} & \multicolumn{2}{|c|}{$\begin{array}{c}\mathrm{K}_{2} \mathrm{O} \\
(\mathrm{mg} \text { per } 100 \mathrm{~g})\end{array}$} & \multicolumn{2}{|c|}{$\underset{(\mathrm{mg} \text { per } 100 \mathrm{~g})}{\mathrm{Mg}}$} & \multicolumn{2}{|c|}{$\begin{array}{c}\mathrm{Ca} \\
\left(\mathrm{mg} \mathrm{dm}^{-3}\right)\end{array}$} & \multicolumn{2}{|c|}{$\begin{array}{c}{\mathrm{S}-\mathrm{SO}_{4}}_{(\mathrm{mg} \text { per } 100 \mathrm{~g})}\end{array}$} \\
\hline & \multicolumn{2}{|c|}{ Season } & \multicolumn{2}{|c|}{ Season } & \multicolumn{2}{|c|}{ Season } & \multicolumn{2}{|c|}{ Season } & \multicolumn{2}{|c|}{ Season } & \multicolumn{2}{|c|}{ Season } & \multicolumn{2}{|c|}{ Season } & \multicolumn{2}{|c|}{ Season } \\
\hline & S & A & S & A & S & A & S & A & $\mathrm{S}$ & $\mathbf{A}$ & $\mathrm{S}$ & A & $\mathrm{S}$ & A & S & $\mathbf{A}$ \\
\hline Degraded soil & 4.25 & 4.24 & $\begin{array}{l}2.05 \\
2.59\end{array}$ & $\begin{array}{l}1.93 \\
2.47\end{array}$ & $\begin{array}{l}10.75 \\
13.64\end{array}$ & $\begin{array}{l}24.75 \\
31.68\end{array}$ & 3.25 & 4.52 & 1.55 & 1.91 & 1.75 & 1.51 & 196 & 183.6 & 0.44 & 0.44 \\
\hline Arable soil & 5.4 & 5.3 & $\begin{array}{l}3.56 \\
4.39\end{array}$ & $\begin{array}{l}3.87 \\
4.93\end{array}$ & $\begin{array}{l}17.62 \\
21.71\end{array}$ & $\begin{array}{l}37.29 \\
47.48\end{array}$ & 39 & 26.47 & 20.15 & 21.89 & 8.45 & 9.19 & 538 & 573.8 & 0.57 & 0.57 \\
\hline
\end{tabular}

Explanations: $\mathrm{S}=$ spring, $\mathrm{A}=$ autumn. The $\mathrm{pH}$ was determined according to Ostrowska et al. [30], and contents of plant-available macronutrient forms were determined in accordance with Ostrowska et al. [30], Polish Standard, PN-R-04023 [31], Polish Standard PN-R-04022 [32], and Polish Standard PN-R-04020 [33].

In the case of maize cultivation, arable soil and a mixture of degraded soil with $5 \%$ $(\mathrm{v} / \mathrm{v})$ Z-ion addition were used as the growing media. Cocksfoot cultivation was performed on arable soil and degraded soil enriched with $1 \%(\mathrm{v} / \mathrm{v})$ Z-ion addition (Table 2). The applied doses of Z-ion substrate resulted from previous studies [34] showing that a $5 \%$ dose of Z-ion substrate to degraded soil yielded the same dry stem biomass of maize compared with that obtained for the arable soil. For cocksfoot, it was stated that the addition of Z-ion substrate not exceeding $1 \%(\mathrm{v} / \mathrm{v})$ - after being added to the degraded soil-yielded a dry stem biomass comparable to that for the arable soil [35]. During media preparation, calcium bicarbonate was mixed with degraded soil (in the dose of about $60 \mathrm{mg}$ per $100 \mathrm{~g}$ of soil) to adjust its $\mathrm{pH}$ to that of the arable soil.

Table 2. Characteristics of growing media used for cultivation of the tested plants.

\begin{tabular}{cccc}
\hline Crop & Medium & $\begin{array}{c}\text { Soil } \\
\left(\mathbf{c m}^{3} \text { per } \mathbf{p o t}\right)\end{array}$ & $\begin{array}{c}\text { Z-Ion Substrate Addition } \\
\left(\mathbf{c m}^{3} \text { per pot }\right)\end{array}$ \\
\hline \multirow{2}{*}{ Maize } & Arable soil & 1150 & - \\
\multirow{2}{*}{ Cocksfoot } & Degraded soil + 5\% Z-ion & 1092 & 57.5 \\
& Arable soil & 300 & - \\
\hline
\end{tabular}

\subsection{Chemical Analysis of Plant Substrates}

After ending plant growth, the shoot biomass of maize and cocksfoot was examined in terms of dry matter (total solids (TS)), dry organic matter (volatile solids (VS)), total organic carbon (TOC), total nitrogen (NT), and protein content. Moreover, the fiber componentsneutral detergent fiber (NDF), acid detergent fiber (ADF), and acid detergent lignin (ADL) were determined. Dry matter was found gravimetrically by drying at $105{ }^{\circ} \mathrm{C}$ [30]. The dry organic matter (VS) was found after ignition of the samples at $450{ }^{\circ} \mathrm{C}[30]$ and determining the ash content $(\mathrm{AC})(\mathrm{VS}(\%)=100(\%)-\mathrm{AC}(\%))$. Total organic carbon was measured by use of RC 62 LECO apparatus (LECO, St Joseph, MO, USA), whereas the nitrogen content was analyzed using KjeltecTM 8200 Foss Tecator system (Foss, Hoganas, Sweden). The outcomes of the TOC and NT analysis were applied to compute the $\mathrm{C} / \mathrm{N}$ ratio in the maize and cocksfoot biomass. The protein content was calculated based on the $\mathrm{N}$ content $(\mathrm{NT} \times 6.25)$. NDF, ADF, and ADL were determined in milled shoot samples via the Van Soest method [36] by means of an ANKOM 220 Fiber Analyzer (ANKOM Technology, Macedon, NY, USA) for extraction of the fiber components. The content of 
hemicellulose and cellulose in the plant biomass was calculated in the following way: cellulose $=\mathrm{ADF}-\mathrm{ADL}$, hemicellulose $=\mathrm{NDF}-\mathrm{ADF}$. Chemical analyses of the plant biomass were carried out in two or three replications.

\subsection{Anaerobic Digestion Experiments}

Batch assays of anaerobic digestion of maize and cocksfoot biomass were performed in BioReactor Simulator (BRS) equipment (BPC Instruments, formerly Bioprocess Control, Sweden) which contained 6 glass bioreactors (each $2300 \mathrm{~cm}^{3}$ in volume) and an automatic system enabling continuous mixing of feedstocks, temperature control, and measurement of the produced biogas volume. Preincubated digestate $\left(1200 \mathrm{~cm}^{3}\right.$ per each bioreactor $)$ from the biogas plant localized in Siedliszczki (Lublin province, Poland) was used as inoculum in the experiment. Preincubation was carried out until biogas production below $10 \mathrm{~cm}^{3} \mathrm{~d}^{-1}$ was maintained for 7 days. The initial $\mathrm{pH}$ of inoculum was $8.33 \pm 0.1$. The tests were carried out in three replicates $(n=3)$. The temperature of the process was maintained at $35^{\circ} \mathrm{C}$. The samples of fresh plant biomass (maize or cocksfoot shoots cut in 3-5 $\mathrm{mm}$ lengths) were introduced into the bioreactors at a dose of $5 \mathrm{~g}$ of dry matter to each bioreactor. Afterward, the bioreactors were closed and flushed with the $\mathrm{N}_{2}$ gas to ensure the anaerobic conditions. Digestion of the plant biomass was continued for 30 days in the case of maize and for 34 days in the case of cocksfoot until the biogas production decreased below $20 \mathrm{~cm}^{3}$ per day. During the process, the volume of the generated biogas was measured by a multi-channel gas volume analyzer, which was a subunit of BRS system. The obtained data were standardized to normal conditions. The methane content in the biogas was determined using a gas chromatograph (Thermo Trace GC Ultra with a TCD detector, Fisher, Switzerland) at the end of the tests. The obtained data were the basis for calculating the biogas potential, methane potential, and energetic potential of the tested plant substrates according to the following formula:

$$
\mathrm{BGP}=\frac{V b}{M w}
$$

where BGP is the biogas potential $\left(\mathrm{Nl}(\mathrm{gTS})^{-1}\right.$ or $\left.\mathrm{Nl}(\mathrm{gVS})^{-1}\right), V b$ is the total volume of biogas produced during the test $(\mathrm{Nl})$, and $M w$ is the mass of the substrate introduced into the bioreactor (without the mass of the inoculum) ( $\mathrm{g}$ of TS or $\mathrm{g}$ of VS):

$$
\mathrm{BMP}=\frac{\mathrm{BGP} \cdot X}{100 \%}
$$

where BMP is the biomethane potential $\left(\mathrm{Nl}(\mathrm{gTS})^{-1}\right.$ or $\left.\mathrm{Nl}(\mathrm{gVS})^{-1}\right)$, BGP is the biogas potential $\left(\mathrm{Nl}(\mathrm{gTS})^{-1}\right.$ or $\left.\mathrm{Nl}(\mathrm{gVS})^{-1}\right)$, and $\mathrm{X}$ is the methane concentration in the biogas (\%):

$$
\mathrm{SE}=\mathrm{BMP} \cdot Q
$$

where SE is the specific energy of the biomass converted into biomethane $\left(\mathrm{GJ}(\mathrm{MgTS})^{-1}\right.$ or $\left.\mathrm{GJ}(\mathrm{MgVS})^{-1}\right)$, BMP is the biomethane potential $\left(\mathrm{Nm}^{3}(\mathrm{MgTS})^{-1}\right.$ or $\left.\mathrm{Nm}^{3}(\mathrm{MgVS})^{-1}\right)$, and $Q$ is the calorific value of methane $\left(\mathrm{MJm}^{-3}\right)$.

\subsection{Statistical Analysis}

Statistica 13.3 software was used to perform statistical analysis. The mean values and standard deviations were calculated for the chemical characteristics of the plant biomass and for the biogas production parameters. The significance of the differences between the compared mean values for the biogas parameters was tested by the Student's $t$ test after prior verification of the variance homogeneity (by the Fisher-Snedecor test) at the 0.05 significance level [37]. 


\section{Results and Discussion}

\subsection{Biogas and Biomethane Production from the Cocksfoot Biomass}

The mean values of the daily and cumulative production of biogas from the cocksfoot biomass obtained in arable soil and degraded soil supplemented with a 1\% Z-ion addition are presented in Figures 1a and 2a. It can be seen that the biogas production in the bioreactors of both test series already started on the first day of the process (Figure 1a). It was the highest on the 2nd day of the process and subsequently lowered quite rapidly at first (until the 7th day of the process) and then gradually, reaching the lowest values from the 11th to 16th day. From the 17th day of the process, a slight increase in biogas production was observed, and then it remained steady (with low fluctuations) until the last day of the process, when the obtained biogas amount was very low. The course of changes in the average daily biogas production was similar for both analyzed feedstocks. However, there were some differences in the amount of biogas produced between the reactors containing the biomass of plants growing in degraded soil supplemented with Z-ion substrate and the reactors containing the biomass of plants growing in arable soil. The greatest differences in terms of the digestion of the cocksfoot biomass were noticed between the 7th and 15th days, when the biogas production of the biomass obtained in degraded soil fertilized with the Z-ion substrate was higher compared with the biomass harvested from the arable soil (Figure 1a). The peaks in daily biogas production observed during the early stages of cocksfoot digestion (on the second day of the process) probably resulted from the hydrolysis rate for carbohydrates (monosaccharides and disaccharides), which is higher compared to those for proteins and fats during anaerobic digestion [38]. The period of low and very low daily biogas production (from the 7th to the 16th day of the process) indicated depletion of fast biodegradable organic compounds, wherein the differences between the tested feedstocks in this period could be explained by the protein content, which was higher in the cocksfoot biomass obtained from the degraded soil fertilized with a Z-ion addition by $42 \%$ than that in the plant biomass obtained from arable soil (Table 3 ). An increase in daily biogas production observed from the 17th day of the process was probably caused by decomposition of fiber fractions like cellulose and hemicellulose, the degradation of which requires a sufficiently long time $[17,38]$. The contents of the fiber fractions were similar in both analyzed feedstocks (differences were not higher than $11 \%$; Table 3). Thus, the daily biogas production from the 17th day of the process was also quite similar for the plant biomass obtained for the arable soil and the degraded soil fertilized with a $1 \%$ Z-ion addition.

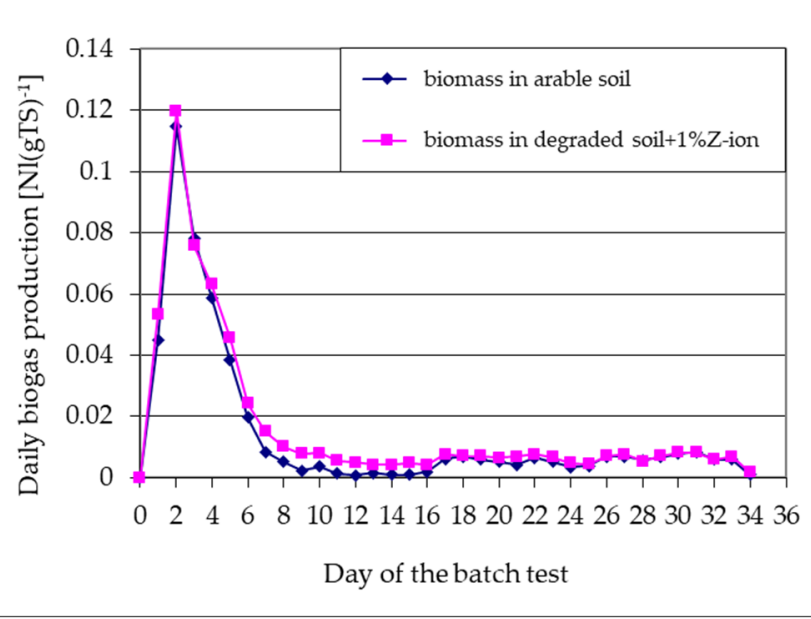

(a)

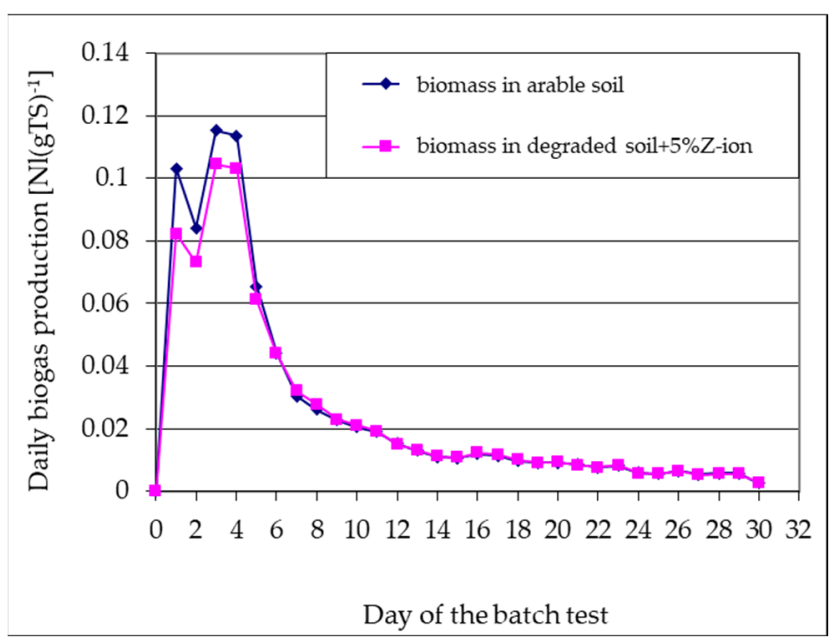

(b)

Figure 1. Daily biogas production for (a) the cocksfoot biomass obtained in arable soil and degraded soil supplemented with a 1\% Z-ion addition, and (b) the maize biomass obtained in arable soil and degraded soil supplemented with a $5 \%$ Z-ion addition (values presented as means, $n=3$ ). 


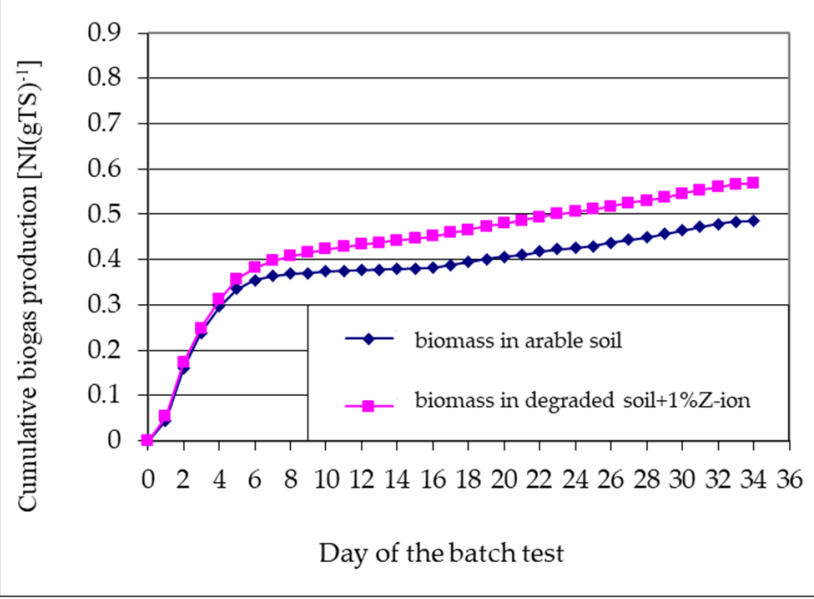

(a)

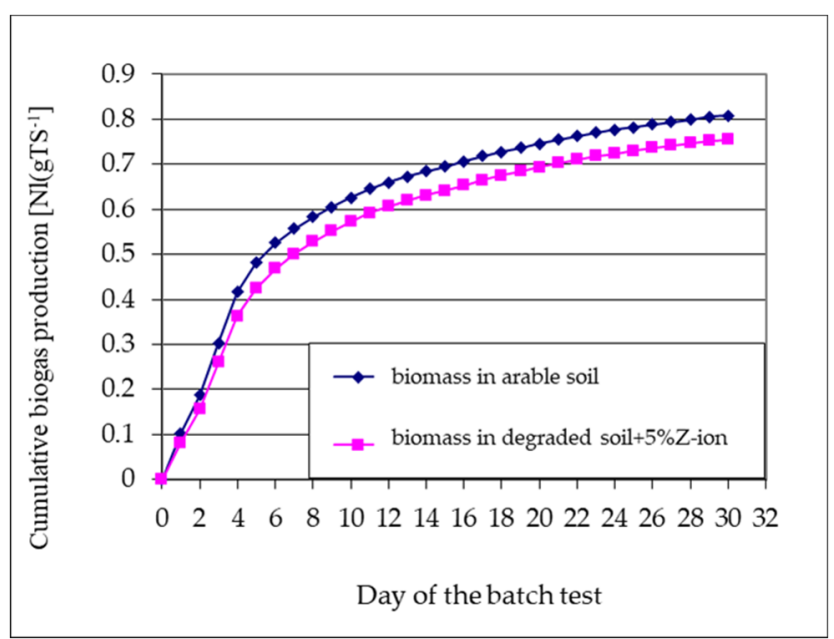

(b)

Figure 2. Cumulative biogas production for (a) the cocksfoot biomass obtained in arable soil and degraded soil supplemented with a $1 \%$ Z-ion addition and (b) the maize biomass obtained in arable soil and degraded soil supplemented with a $5 \%$ Z-ion addition (values presented as means, $n=3$ ).

Table 3. Chemical composition of the cocksfoot biomass used in the batch digestion test.

\begin{tabular}{|c|c|c|c|c|c|c|c|c|c|c|}
\hline Medium & $\begin{array}{c}\text { VS } \\
\% \text { of TS }\end{array}$ & $\begin{array}{c}\text { C } \\
\% \text { of TS }\end{array}$ & $\begin{array}{c}\mathrm{N} \\
\% \text { of TS }\end{array}$ & $\mathrm{C} / \mathrm{N}$ & $\begin{array}{l}\text { Protein } \\
\% \text { of TS }\end{array}$ & $\begin{array}{c}\text { NDF } \\
\mathrm{g}\left(\mathrm{kgTS}^{-1}\right.\end{array}$ & $\begin{array}{c}\text { ADF } \\
{\text { g(kgTS })^{-1}}^{-1}\end{array}$ & $\begin{array}{c}\text { ADL } \\
{\mathrm{g}(\mathrm{kgTS})^{-1}}^{-1}\end{array}$ & $\begin{array}{l}\text { Cellulose } \\
\mathrm{g}(\mathrm{kgTS})^{-1}\end{array}$ & $\begin{array}{l}\text { Hemicellulose } \\
\text { g(kgTS) })^{-1}\end{array}$ \\
\hline Arable soil & $92.54 \pm 0.40$ & $46.66 \pm 0.19$ & $1.12 \pm 0.006$ & 41.7 & $7.00 \pm 0.04$ & $442 \pm 3.08$ & $214 \pm 3.86$ & $21.4 \pm 0.46$ & 192.6 & 228.0 \\
\hline $\begin{array}{l}\text { Degraded soil } \\
+1 \% \text { Z-ion }\end{array}$ & $95.11 \pm 0.003$ & $49.33 \pm 0.32$ & $1.59 \pm 0.015$ & 31.0 & $9.94 \pm 0.09$ & $454 \pm 0.00$ & $200 \pm 1.54$ & $20.6 \pm 1.31$ & 179.4 & 254.0 \\
\hline
\end{tabular}

Explanations: $\mathrm{VS}=$ volatile solids, $\mathrm{TS}=$ total solids, $\mathrm{NDF}=$ neutral detergent fiber, $\mathrm{ADF}=$ acid detergent fiber, $\mathrm{ADL}=$ acid detergent lignin, and $\pm=$ standard deviation .

The cumulative biogas production in the bioreactors of both analyzed series increased quickly until the fifth day of the process, and in this period, it was very similar for the plant biomass obtained in arable soil and degraded soil enriched with a Z-ion addition (Figure 2a). From the sixth day of the process, the increases in cumulative biogas production were lower, and differences in the values of this parameter between the considered feedstocks appeared (in the range of 7-19\%). The biogas potential of the cocksfoot biomass obtained from the arable soil (calculated at the end of the process per $g$ of TS and VS) was numerically lower than that found for the cocksfoot biomass obtained from the degraded soil amended with a Z-ion addition. However, the differences between the compared values were not statistically significant (Table 4). Similarly, there were no significant differences in the values of biomethane production and specific energy of the biomass converted into biomethane (at practically the same methane concentration in the produced biogas) between the compared feedstocks (Table 4). Thus, at a higher nitrogen content and lower $\mathrm{C} / \mathrm{N}$ ratio in the biomass harvested from the degraded soil with added Z-ion, as opposed to those in the biomass obtained from the arable soil (Table 3), a significant increase in the biogas production characteristics for the cocksfoot growing on the former was not observed, compared with those for the plants cultivated in the latter soil.

Table 4. Biogas and biomethane potentials and specific energy of cocksfoot biomass.

\begin{tabular}{|c|c|c|c|c|c|c|c|}
\hline Medium & $\begin{array}{c}\text { BGP } \\
\mathrm{Nl}^{(\mathrm{gTS})^{-1}}\end{array}$ & $\begin{array}{c}\text { BMP } \\
\mathrm{Nl}^{(\mathrm{gTS})^{-1}}\end{array}$ & $\begin{array}{c}\text { SE } \\
\mathrm{GJ}^{\mathrm{MgTS})^{-1}}\end{array}$ & $\underset{\%}{\mathrm{CH}_{4}}$ & $\begin{array}{c}\text { BGP } \\
\mathrm{Nl}(\mathrm{gVS})^{-1}\end{array}$ & $\begin{array}{c}\text { BMP } \\
\mathrm{Nl}^{(\mathrm{gVS})^{-1}}\end{array}$ & $\begin{array}{c}\text { SE } \\
\text { GJ(MgVS)-1 }\end{array}$ \\
\hline Arable soil & $0.485 \pm 0.012$ & $0.287 \pm 0.008$ & $10.262 \pm 0.270$ & $59.06 \pm 0.16$ & $0.525 \pm 0.013$ & $0.310 \pm 0.008$ & $11.110 \pm 0.292$ \\
\hline Degraded soil $+1 \%$ Z-ion & $0.568 \pm 0.065$ & $0.334 \pm 0.033$ & $11.957 \pm 1.168$ & $58.87 \pm 0.90$ & $0.599 \pm 0.068$ & $0.352 \pm 0.034$ & $12.603 \pm 1.231$ \\
\hline
\end{tabular}

Explanations: $\mathrm{TS}=$ total solids, VS = volatile solids, $\mathrm{BGP}=$ biogas potential, $\mathrm{BMP}=$ biomethane potential, $\mathrm{SE}=$ specific energy, and $\pm=$ standard deviation. 
By comparing the obtained results with those of earlier studies described in the literature, it can be said that the values of the biomethane potentials (per g of TS and VS) were in the ranges found for the cocksfoot biomass by Seppälä et al. [2]. However, the BMP values of the biomass obtained in arable soil were at the lower limits of the ranges, whereas the BMP values of the biomass obtained in degraded soil amended with a Z-ion addition were at the higher limits of the ranges. The BMP values determined for both feedstocks in the present study were higher than those $\left(0.245-0.207 \mathrm{Nl}(\mathrm{gVS})^{-1}\right)$ reported for cocksfoot by McEniry and $\mathrm{O}^{\prime}$ Kiely [10]. The reason for this could be the higher content of lignin (ADL in cocksfoot biomass used by the aforementioned authors), which is practically not an anaerobically biodegradable compound because the extracellular enzymes required for its depolymerization need molecular oxygen $[39,40]$. It should be added that the plants examined by McEniry and O'Kiely [10] were harvested at a more advanced growth stage (as opposed to the growth stage of the cocksfoot harvested in the present study). Thus, they could contain more crystalline cellulose, which is less biodegradable than the amorphous type [17]. The biogas and biomethane potentials of cocksfoot biomass obtained in the degraded soil enriched with a Z-ion addition were basically in the range of the values determined by Butkute et al. [17], but the biogas parameters for the plant biomass obtained in the arable soil were lower than those reported by the aforementioned authors. It needs to be highlighted that Butkute et al. [17] harvested cocksfoot at a more advanced maturity stage, and although its biomass contained more lignin and cellulose compared with the cocksfoot used in the present study, it was also characterized by a more appropriate $\mathrm{C} / \mathrm{N}$ ratio (18.8-34.4 as opposed to 41.7 for the cocksfoot in arable soil; Table 3) and sometimes by a higher content of hemicellulose (209-252 $\mathrm{g} \mathrm{kg}^{-1}$ of TS), which is a heterogenic and quite readily hydrolysable polymer [17].

While comparing the results of the present studies with those obtained for different grass species under conditions of batch assays [2,10,17,41], it was revealed that the biomethane potential of the cocksfoot biomass obtained in the arable soil and degraded soil supplemented with a Z-ion addition were of the same order of magnitude as those reported for the biomass of timothy $\left(0.230-0.248 ; 0.308-0.365 \mathrm{Nl}(\mathrm{gVS})^{-1}\right)$, tall fescue $(0.224-0.255$; $\left.0.296-0.394 ; 0.266-0.396 \mathrm{Nl}(\mathrm{gVS})^{-1}\right)$, Italian ryegrass $\left(0.236-0.254 \mathrm{Nl}(\mathrm{gVS})^{-1}\right)$, perennial ryegrass $\left(0.229-0.263 \mathrm{Nl}(\mathrm{gVS})^{-1}\right)$, reed canary grass $\left(0.253-0.351 ; 0.316-0.426 \mathrm{Nl}(\mathrm{gVS})^{-1}\right)$, or a Poa spp. and Festuca spp. mixture $\left(0.340 \mathrm{Nl}(\mathrm{gVS})^{-1}\right)$, as well as a Poa spp., Festuca spp., Sorghum spp., and Phragmites spp. mixture $\left(0.308 \mathrm{Nl}(\mathrm{gVS})^{-1}\right)$. Distinctly lower values of biomethane potential compared with those obtained in the present study, were found by Lehtomäki et al. [39] in the experiments with leach bed reactors, where the silage prepared from timothy and meadow fescue were used as feedstock. The high lignin content in the applied feedstock, the inhibitory effect of hydrochloric acid which was used for $\mathrm{pH}$ adjustment, or too low of a substrate/inoculum ratio in particular modes of digestion performance could be reasons for that [39].

\subsection{Biogas and Biomethane Production from Maize Biomass}

The mean values of the daily and cumulative production of biogas from the maize biomass obtained in arable soil and degraded soil enriched with a 5\% Z-ion addition are presented in Figures $1 \mathrm{~b}$ and $2 \mathrm{~b}$. Biogas production in the bioreactors containing the tested feedstocks already started on the first day of the process (Figure 1b) when the first peaks in the biogas production were observed. Then, biogas production slightly decreased (on the second day), and afterward it increased again (the third and fourth day of the process), which is demonstrated in the graphs by the second and highest peaks. From the fourth day of the process, the biogas production lowered quickly at first (until the seventh day of the process) and then gradually until it reached the lowest value at the end of the experiment (Figure 1b). The course of changes in the average daily biogas production was similar for both analyzed feedstocks. However, during the first 4 days of the process, biogas production for the biomass obtained in arable soil was higher than that found for the biomass harvested from degraded soil supplemented with a 5\% Z-ion 
addition (by $10-25 \%$ ). The observed peaks in daily biogas production probably resulted from decomposition of the fast biodegradable mono- and disaccharides (the first peaks) and proteins (the second peaks; Figure 1b). The peaks observed on the curve illustrating biogas production from the biomass obtained in degraded soil amended with $5 \%$ Z-ion were lower than those found on the curve for the biomass obtained in arable soil, which could be related to more unfavorable conditions for the course of the anaerobic digestion process (during the first 4 days) resulting from the considerably lower $\mathrm{C} / \mathrm{N}$ ratio found in the maize biomass harvested from degraded soil with $5 \% \mathrm{Z}$-ion added (the low $\mathrm{C} / \mathrm{N}$ ratio in the plant biomass was caused by higher $\mathrm{N}$ uptake due to the nitrogen content in the Z-ion substrate; Table 5). It is known that the optimal $\mathrm{C} / \mathrm{N}$ ratio for feedstock biomethanization ranges from 20 to 30, and at lower carbon/nitrogen ratios, the accumulation of $\mathrm{NH}_{4}{ }^{+}$ions in the feedstock is possible, which may inhibit the activity of methanogenic bacteria [42].

Table 5. Chemical composition of the maize biomass used in the batch digestion test.

\begin{tabular}{|c|c|c|c|c|c|c|c|c|c|c|}
\hline Medium & $\begin{array}{c}\text { VS } \\
\% \text { of TS }\end{array}$ & $\begin{array}{c}\text { C } \\
\% \text { of TS }\end{array}$ & $\underset{\% \text { of TS }}{N}$ & $\mathrm{C} / \mathrm{N}$ & $\begin{array}{l}\text { Protein } \\
\% \text { of TS }\end{array}$ & $\begin{array}{c}\text { NDF } \\
{\text { g(kgTS })^{-1}}^{-1}\end{array}$ & $\begin{array}{c}\text { ADF } \\
\mathrm{g}\left(\mathrm{kgTS}^{-1}\right.\end{array}$ & $\begin{array}{c}\text { ADL } \\
{\text { g(kgTS })^{-1}}^{-1}\end{array}$ & $\begin{array}{l}\text { Cellulose } \\
\text { g(kgTS) }{ }^{-1}\end{array}$ & $\begin{array}{l}\text { Hemicellulose } \\
{\text { g(kgTS })^{-1}}^{\text {(kgTe }}\end{array}$ \\
\hline Arable soil & $93.71 \pm 0.36$ & $49.27 \pm 0.38$ & $1.41 \pm 0.03$ & 35.0 & $8.80 \pm 0.20$ & $564 \pm 1.56$ & $297 \pm 3.89$ & $22.1 \pm 1.09$ & 274.9 & 267.0 \\
\hline $\begin{array}{c}\text { Degraded soil } \\
+5 \% \\
\text { Z-ion }\end{array}$ & $87.93 \pm 0.26$ & $47.45 \pm 0.49$ & $3.57 \pm 0.01$ & 13.3 & $\begin{array}{c}22.29 \pm \\
0.06\end{array}$ & $531 \pm 2.34$ & $295 \pm 3.12$ & $37.0 \pm 2.88$ & 258.0 & 236.0 \\
\hline
\end{tabular}

Explanations: $\mathrm{VS}=$ volatile solids, $\mathrm{TS}=$ total solids, $\mathrm{NDF}=$ neutral detergent fiber, $\mathrm{ADF}=$ acid detergent fiber, $\mathrm{ADL}=$ acid detergent lignin, and $\pm=$ standard deviation

The period of a fast increase in cumulative biogas production for both compared feedstocks lasted 5 days (Figure 2b). During this time, the differences between the biogas production of the considered substrates did not exceed 25\%. From the sixth day of the process, increases in the cumulative production for particular tested substrates were lower, and differences in the values of biogas production between both tested maize biomasses remained at the level of $7-12 \%$. The values of the biogas and methane potentials and the specific energy of the maize biomass obtained in arable soil (calculated per total solids at the end of the process) were significantly higher than those found for the maize biomass obtained in degraded soils supplemented with $5 \%$ Z-ion. However, the differences between the compared parameters numerically were not higher than $7 \%$ (Table 6). These differences could be explained by the slightly higher content of volatile solids (as potentially biodegradable process substrates) in the dry biomass of maize growing in arable soil (Table 5). The methane content in the produced biogas, biogas, and biomethane potentials, as well as the specific energy calculated per unit of volatile solids, were practically the same for both the compared feedstocks (Table 6).

Table 6. Biogas and biomethane potential and specific energy of maize biomass.

\begin{tabular}{|c|c|c|c|c|c|c|c|}
\hline Medium & $\begin{array}{c}\text { BGP } \\
\mathrm{Nl}^{\left(\text {gTS }^{-1}\right.}\end{array}$ & $\begin{array}{c}\text { BMP } \\
\mathrm{Nl}^{(\mathrm{gTS})^{-1}}\end{array}$ & $\begin{array}{c}\text { SE } \\
{\text { GJ(MgTS })^{-1}}^{-1}\end{array}$ & $\underset{\%}{\mathrm{CH}_{4}}$ & $\begin{array}{c}\text { BGP } \\
\mathrm{Nl}\left(\mathrm{gVS}^{-1}\right.\end{array}$ & $\begin{array}{c}\text { BMP } \\
\mathrm{Nl}^{(\mathrm{gVS})^{-1}}\end{array}$ & $\begin{array}{c}\text { SE } \\
\left.\mathrm{GJ}^{(M g V S}\right)^{-1}\end{array}$ \\
\hline Arable soil & $0.808 \pm 0.012$ & $0.484 \pm 0.009$ & $17.323 \pm 0.358$ & $59.89 \pm 0.57$ & $0.862 \pm 0.013$ & $0.516 \pm 0.011$ & $18.485 \pm 0.382$ \\
\hline $\begin{array}{c}\text { Degraded soil }+5 \% \\
\text { Z-ion }\end{array}$ & $0.755 \pm 0.006 *$ & $0.458 \pm 0.003 *$ & $16.386 \pm 0.100 *$ & $60.60 \pm 0.16$ & $0.859 \pm 0.007$ & $0.520 \pm 0.003$ & $18.635 \pm 0.114$ \\
\hline
\end{tabular}

Explanations: $\mathrm{TS}=$ total solids, VS = volatile solids, $\mathrm{BGP}=$ biogas potential, $\mathrm{BMP}=$ biomethane potential, $\mathrm{SE}=$ specific energy, and $\pm=$ standard deviation. ${ }^{*}$ Differences between values of biogas parameters are statistically significant $(\alpha=0.05)$.

The biogas and biomethane potentials determined for both maize feedstocks in this research were higher than those found by Oslaj et al. [43] for the maize hybrids of maturity class FAO 300-FAO 400 (biogas potential: $0.455-0.544 \mathrm{Nl}(\mathrm{gVS})^{-1}$, methane potential: $0.251-0.312 \mathrm{Nl}\left(\mathrm{gVS}^{-1}\right)$, FAO 400-FAO 500 (biogas potential: $0.507-0.603 \mathrm{Nl}(\mathrm{gVS})^{-1}$, methane potential: $0.281-0.349 \mathrm{Nl}\left(\mathrm{gVS}^{-1}\right.$ ), and FAO 500-FAO 600 (biogas potential: $0.521-0.559 \mathrm{Nl}(\mathrm{gVS})^{-1}$, methane potential: $\left.0.294-0.330 \mathrm{Nl}(\mathrm{gVS})^{-1}\right)$. Similarly, the biomethane potentials of the maize growing in arable soil and degraded soil supplemented with a 
Z-ion substrate were greater than the values reported by Bruni et al. [44] for six maize varieties which differed in terms of ripening time (in the range of $0.3-0.4 \mathrm{Nl}(\mathrm{gVS})^{-1}$ ) or by Schittenhelm [45] for five maize hybrids of widely contrasting maturities (in the ranges of $0.287-0.419 \mathrm{Nl}(\mathrm{gVS})^{-1}$ and $\left.0.282-0.379 \mathrm{Nl}(\mathrm{gVS})^{-1}\right)$. The reasons for this could be the lower protein content [43-45] and higher content of lignin-ADL [43] in the hybrids tested by the aforementioned researchers compared with the maize used in the present study (Table 6). It is worth pointing out that the cited authors used maize plants harvested at a more advanced stage of maturity, and thus they could contain more crystalline form of cellulose which, as previously mentioned, is less biodegradable than the amorphous form.

Regarding the necessity of year-round availability of the feedstock for agricultural biogas plants, maize biomass is usually used in silage form [46,47]. Thus, the biogas parameters determined in the presented studies were compared with those reported in the scientific literature for maize silage. It appeared that the biogas or biomethane potentials for the raw biomass of maize growing in arable soil and degraded soil supplemented with a Z-ion substrate were higher than the values of biogas production found by Amon et al. [48], Hutnan et al. [46], Klimiuk et al. [40], or Giessen et al. [49] for maize silage. The differences between the parameters obtained in the present study and reported by the afore-mentioned authors were in the range of $22-58 \%$ and could result from different modes of digestion performance (continuous mode used in the studies by Hutnan et al. and Klimiuk et al.) or chemical compositions of the applied feedstocks which might contain more lignin (the plants in the cited papers were harvested at a more advanced growth stage as opposed to the maize used in the present study).

\section{Conclusions}

The results of the present study indicated that under the experimental conditions, the application of $1 \%$ (in the case of cocksfoot) or $5 \%$ by volume (in the case of maize) of Z-ion addition to degraded, acidic, and unfertile soil enabled obtaining the biomasses of the examined species with a quality similar, in terms of suitability as feedstock for energy production in biogas plants, to those harvested in arable soil. Due to different nitrogen requirements, the substrate dose needed to obtain a cocksfoot biomass yield in degraded soil similar to that harvested from the control arable soil was five times lower than that found in the case of maize.

The application of Z-ion additions in the aforementioned doses to the degraded soil caused an increase in the nitrogen content in the plant biomass, which resulted in a decrease in the $\mathrm{C} / \mathrm{N}$ ratio to optimal (in the case of cocksfoot biomass) and suboptimal (in the case of maize biomass) levels, considering the conditions of anaerobic digestion. However, the last one did not negatively influence the final biogas and biomethane production or the specific energy of the maize biomass.

The study results indicated the usefulness of Z-ion substrate to improve the growth conditions for energy crops in degraded soils and, as a consequence, to obtain a plant feedstock for the digestion process. Since the studies were carried out on a laboratory scale, their results should be verified under open-air plant vegetative growth experiments to estimate the influence of changeable environmental conditions and determine the biomass yield per hectare. Special attention should be paid to the differences in biomass yields per hectare caused by the stage of plant growth or subsequent swaths (in the case of cocksfoot). Future studies can be also focused on estimating the influence of time-dependent changes in the biomass composition of the plants cultivated in the soils amended with Z-ion substrate on the biogas production and energy potential of the crops related to the unit field area.

A plant species with low soil requirements (e.g., Sakhalin knotweed (Reynoutria sachalinensis (F. Schmidt, Nakai)), alfalfa (Medicago sativa L.), or vetch (Vicia sativa L.)) might be considered in further field studies on the use of the Z-ion substrate for enhancing plant growth in reclaimed soils. The potentially high yield of the above-ground biomass of these plants could be used for biogas production, while an extensive root system would increase carbon sequestration in the reclaimed soil. It seems that the use of the studied 
zeolite substrate may be particularly advantageous in the early growth stages of legumes which, living in symbiosis with rhizobia, are able to absorb atmospheric nitrogen. Owing to this, it will be possible to achieve a rapid increase in biomass yield in the first years of soil reclamation, while the need for fertilizing the reclaimed soil should decrease with time.

Author Contributions: Conceptualization, M.C. and M.P.; methodology, M.C. and M.P.; validation, M.C. and M.P.; investigation, M.C., M.P., O.S. and E.D.; resources, M.C. and M.P.; writing-original draft preparation, M.C.; writing-review and editing, M.C. and M.P.; visualization, M.C. and M.P.; supervision, M.C. and M.P.; funding acquisition, M.C. and M.P. All authors have read and agreed to the published version of the manuscript.

Funding: This research was funded by the Ministry of Education and Science, grant number FD20/IS-6/999 and FD-20/IS-6/026.

\section{Institutional Review Board Statement: Not applicable.}

Informed Consent Statement: Not applicable.

Acknowledgments: The authors express their gratitude toward Vladimir Soldatov and Igor Mielnikov for providing the Z-ion substrate.

Conflicts of Interest: The authors declare no conflict of interest.

\section{References}

1. Fritsche, U.R.; Sims, R.E.H.; Monti, A. Direct and indirect land-use competition issues for energy crops and their sustainable production-An overview. Biofuel Bioprod. Biorefining 2010, 4, 692-704. [CrossRef]

2. Seppälä, M.; Paavola, T.; Lehtomäki, A.; Rintala, J. Biogas production from boreal herbaceous grasses-Specific methane yield and methane yield per hectare. Bioresour. Technol. 2009, 100, 2952-2958. [CrossRef]

3. Li, Y.; Park, S.Y.; Zhu, J. Solid-state anaerobic digestion for methane production from organic waste. Renew. Sustain. Energy Rev. 2011, 15, 821-826. [CrossRef]

4. Chodkowska-Miszczuk, J.; Martinat, S.; van der Horst, D. Changes in feedstocks of rural anaerobic digestion plants: External drivers towards a circular bioeconomy. Renew. Sustain. Energy Rev. 2021, 148, 111344. [CrossRef]

5. Struk, M.; Vítězová, M.; Vítěz, T.; Bartoš, M.; Kushkevych, I. Modřice Plant Anaerobic Digester: Microbial Distribution and Biogas Production. Water Air Soil Pollut. 2019, 230, 240. [CrossRef]

6. Kushkevych, I.; Kobzová, E.; Vítězová, M.; Vítěz, T.; Dordević, D.; Bartoš, M. Acetogenic microorganisms in operating biogas plants depending on substrate combinations. Biologia 2019, 74, 1229-1236. [CrossRef]

7. Tilvikiene, V.; Venslauskas, K.; Povilaitis, V.; Navickas, K.; Zuperka, V.; Kadziuliene, Z. The effect of digestate and mineral fertilisation of cocksfoot grass on greenhouse gas emissions in a cocksfoot based biogas production system. Energy Sustain. Soc. 2020, 10, 13. [CrossRef]

8. Previtali, D.; Vita, A.; Bassani, A.; Italiano, C.; Amaral, A.F.; Pirola, C.; Pino, L.; Palella, A.; Manenti, F. Methanol Synthesis: A Distributed Production Concept Based on Biogas Plants. Chem. Eng. Trans. 2018, 65, 409-414.

9. Herrmann, C.; Idler, C.; Heiermann, M. Biogas crops grown in energy crop rotations: Linking chemical composition and methane production characteristics. Bioresour. Technol. 2016, 206, 23-35. [CrossRef] [PubMed]

10. McEniry, J.; O'Kiely, P. Anaerobic methane production from five common grassland species at sequential stages of maturity. Bioresour. Technol. 2013, 127, 143-150. [CrossRef]

11. Nabel, M.; Barbosa, D.B.P.; Korsch, D.; Jablonowski, N.D. Energy crop (Sida hermaphrodita) fertilization using digestate under marginal soil conditions: A dose-response experiment. Energy Procedia 2014, 59, 127-133. [CrossRef]

12. Mocek-Płóciniak, A. Biological reclamation of areas degraded after the excavation of lignite and copper ores. Nauka Przyr. Tech. 2014, 8, 1-9. (In Polish)

13. Stańczyk, K.; Ludwik, M. Cultivation of energy crops-Possibility of development of wastelands and arable lands where agricultural production is unprofitable. Pr. Nauk. GIG Górnictwo I Środowisko 2003, 3, 71-81. (In Polish)

14. Natywa, M.; Selwet, M.; Maciejewski, T. Effect of some agrotechnical factors on the number and activity soil microorganisms. Frag. Agron. 2014, 31, 56-63. (In Polish)

15. Wallenius, K.; Rita, H.; Mikkonen, A.; Lappi, K.; Lindström, K.; Hartikainen, H.; Raateland, A.; Niemi, R.M. Effects of land use on the level, variation and spatial structure of soil enzyme activities and bacterial communities. Soil Biol. Biochem. 2011, 43, 1464-1473. [CrossRef]

16. Fageria, N.K.; Moreira, A. The role of mineral nutrition on root growth of crop plants. In Advances in Agronomy; Sparks, D.L., Ed.; Academic Press: San Diego, CA, USA, 2011; Volume 110, pp. 251-331.

17. Butkute, B.; Lemeziene, N.; Kanapeckas, J.; Navickas, K.; Dabkevicius, Z.; Venslauskas, K. Cocksfoot, tall fescue and reed canary grass: Dry matter yield, chemical composition and biomass convertibility to methane. Biomass Bioenergy 2014, 66, 1-11. [CrossRef] 
18. Blanco-Canqui, H. Growing Dedicated Energy Crops on Marginal Lands and Ecosystem Services. Soil. Sci. Soc. Am. J. 2016, 80, 845-858. [CrossRef]

19. GEF. Sustainable Land Management and its Relationship to Global Environmental Benefits an Food Security-A Synthesis Report for the GEF; GEF/STAP/C.50/Inf.03; Global Environment Facility: Washington, DC, USA, 2016; Available online: https://www.thegef org/sites/default/files/council-meetingdocments/EN_GEF.STAP_.C.50.nf_.03_SLM_GEBs_and_Food_Security_0.pdf (accessed on 16 December 2021).

20. Fritsche, U.R.; Berndes, G.; Cowie, A.L.; Dale, V.H.; Kline, K.L.; Johnson, F.X.; Langeveld, H.; Sharma, N.; Watson, H.; Woods, J. Energy and Land Use. Available online: https://knowledge.unccd.int/sites/default/files/2018-06/2.\%20Fritsche\%2Bet $\% 2 B a l \%$ 2B\%282017\%29\%2BEnergy\%2Band\%2BLand\%2BUse\%2B-\%2BGLO\%2Bpaper-corr.pdf (accessed on 16 December 2021).

21. Zhang, X.; Fu, J.; Lin, G.; Jiang, D.; Yan, X. Switchgrass-based bioethanol productivity and potential environmental impact from marginal lands in China. Energies 2017, 10, 260. [CrossRef]

22. Li, Z.; Deng, X.; Chu, X.; Jin, G.; Qi, W. An outlook on the biomass energy development out to 2100 in China. Comput. Econ. 2017, 54, 1359-1377. [CrossRef]

23. Amaral, A.F.; Previtali, D.; Bassani, A.; Italiano, C.; Palella, A.; Pino, L.; Vita, A.; Bozzano, G.; Pirola, C.; Manenti, F. Biogas beyond CHP: The HPC (heat, power \& chemicals) process. Energy 2020, 203, 117820.

24. Wagner, M.; Mangold, A.; Lask, J.; Petig, E.; Andreas, K.A.; Lewandowski, I. Economic and environmental performance of miscanthus cultivated on marginal land for biogas production. Glob. Change Biol. Bioenergy 2019, 2019. 11, 34-49. [CrossRef]

25. Chomczyńska, M.; Pristavko, S.; Soldatov, V.; Wasag, H. The influence of ion-exchange substrates on grass growth in sandy soils. J. Plant Nutr. Soil Sci. 2014, 177, 438-442. [CrossRef]

26. Soldatov, V.S. Artificial soils on the base of synthetic ion exchangers. In Proceedings of the III International Symposium on Growing Media, Composting and Substrate Analysis, Milano, Italy, 24-28 June 2019.

27. Chomczyńska, M.; Soldatov, V.; Wasag, H.; Turski, M. The effect of ion exchange substrate on grass root development and cohesion of sandy soil. Int. Agrophys. 2016, 30, 293-300. [CrossRef]

28. Chomczyńska, M. Restoration of degraded soils using ion exchange materials. Monogr. KIŚ PAN 2013, 110, 1-145. (In Polish)

29. Kosandrovich, E.G.; Soldatov, V.S.; Krasinskaya, T.V.; Kosandrovich, S.Y.; Ionova, O.V.; Yezubets, H.P.; Vonsovich, N.V.; Melnikov, I.O.; Saprykin, V.V. Universal nitrate free nutrient substrates based on chemically modified natural clinoptilolites. In Proceedings of the III International Symposium on Growing Media, Composting and Substrate Analysis, Milano, Italy, 24-28 June 2019.

30. Ostrowska, A.; Gawliński, S.; Szczubiałka, Z. Methods for Analysis and Evaluation of Soil and Plant Properties; Instytut Ochrony Środwiska: Warsaw, Poland, 1991; pp. 1-334. (In Polish)

31. Polish Standard PN-R-04023; Agrochemical Soil Analysis-Determination of Assimilated Phosphorus Content in Mineral Soil. Polski Komitet Normalizacyjny: Warsaw, Poland, 1996; 1-4. (In Polish). (In Polish)

32. Polish Standard PN-R-04022; Agrochemical Soil Analysis-Determination of Assimilated Potassium Content in Mineral Soil. Polski Komitet Normalizacyjny: Warsaw, Poland, 1996; 1-4. (In Polish). (In Polish)

33. Polish Standard PN-R-04020; Agrochemical Soil Analysis-Determination of Assimilated Magnesium Content in Mineral Soil. Polski Komitet Normalizacyjny: Warsaw, Poland, 1994; 1-4. (In Polish). (In Polish)

34. Chomczyńska, M.; Zdeb, M. The Effect of Z-ion Zeolite Substrate on Growth of Zea mays L. as Energy Crop Growing on Marginal Soil. J. Ecol. Eng. 2019, 20, 253-260. [CrossRef]

35. Chomczyńska, M.; Rycko, N. The Application of Z-Ion Substrate to Support Energy Crop Growth (Dactylis glomerata L.) on Degraded Soil. J. Ecol. Eng. 2021, 22, 1-8. [CrossRef]

36. Van Soest, P.J. Use of detergents in the analysis of fibrous feeds. II. A rapid method for the determination of fibre and lignin. J. AOAC 1963, 46, 829-835. [CrossRef]

37. Wołek, J. Introduction to Statistics for Biologists; Scientific Publishing House of Pedagogical University in Cracow: Cracow, Poland, 2007; pp. 1-499. (In Polish)

38. Bulak, P.; Proc, K.; Pawłowska, M.; Kasprzycka, A.; Berus, W.; Bieganowski, A. Biogas generation from insects breeding post production wastes. J. Clean. Prod. 2020, 244, 118777. [CrossRef]

39. Lehtomäki, A.; Huttunen, S.; Lehtinen, T.M.; Rintala, J.A. Anaerobic digestion of grass silage in batch leach bed processes for methane production. Bioresour. Technol. 2008, 99, 3267-3278. [CrossRef]

40. Klimiuk, E.; Pokoj, T.; Budzynski, W.; Dubis, D. Theoretical and observed biogas production from plant biomass of different fibre contents. Bioresour. Technol. 2010, 101, 9527-9535. [CrossRef]

41. Chiumenti, A.; Boscaro, D.; da Borso, F.; Sartori, L.; Pezzuolo, A. Biogas from Fresh Spring and Summer Grass: Effect of the Harvesting Period. Energies 2018, 11, 1466. [CrossRef]

42. Abbasi, T.; Tauseef, S.M.; Abbasi, S.A. Biogas Energy; Springer: New York, NY, USA, 2012; pp. 1-169.

43. Oslaj, M.; Mursec, B.; Vindis, P. Biogas production from maize hybrids. Biomass Bioenergy 2010, 34, 1538-1545. [CrossRef]

44. Bruni, E.; Jensen, A.P.; Pedersen, E.; Angelidaki, I. Anaerobic digestion of maize focusing on variety, harvest time and pretreatment. Appl. Energy 2010, 87, 2212-2217.

45. Schittenhelm, S. Chemical composition and methane yield of maize hybrids with contrasting maturity. Eur. J. Agron. 2008, 29, 72-79. [CrossRef]

46. Hutňan, M.; Špalková, V.; Bodík, I.; Kolesárová, N.; Lazor, M. Biogas Production from Maize Grains and Maize Silage. Pol. J. Environ. Stud. 2010, 19, 323-329. 
47. Mazurkiewicz, J.; Marczuk, A.; Pochwatka, P.; Kujawa, S. Maize Straw as a Valuable Energetic Material for Biogas Plant Feeding. Materials 2019, 12, 3848. [CrossRef] [PubMed]

48. Amon, T.; Amon, B.; Kryvoruchko, V.; Machmuller, A.; Hopfner-Sixt, K.; Bodiroza, V.; Hrbek, R.; Friedel, R.; Potsch, E.; Wagentristl, $\mathrm{H}$; ; et al. Methane production through anaerobic digestion of various energy crops grown in sustainable crop rotations. Bioresour. Technol. 2007, 98, 3204-3212. [CrossRef]

49. Gissén, C.; Prade, T.; Kreuger, E.; Achu Nges, I.; Rosenqvist, H.; Sven-Erik Svensson, S.E.; Lantz, M.; Mattsson, J.E.; Börjesson, P.; Björnsson, L. Comparing energy crops for biogas production. Yields, energy input and costs in cultivation using digestate and mineral fertilization. Biomass Bioenergy 2014, 64, 199-210. [CrossRef] 